\title{
RECONSIDERING THE SELF IN SOCIAL THOUGHT: EXISTENTIAL- PHENOMENOLOGICAL AND DIALOGICAL PERSPECTIVES
}

Charalambos Tsekeris, Academy of Athens, Greece.

\begin{abstract}
The present article attempts to draw a general analytical framework within which to reconsider the notion of the self in the wide interdisciplinary field of social thought. This reconsideration pertains to the self as a fluid social process and as an interrelational meaningful outcome constituent of lived experience, which is neither intrapsychically located, nor able to be defined in isolation, as something "in and of itself". The self is therefore seen as paradoxically both autonomous and interdependent, that is reflexively open, socially embedded and interactively constituted. Our critical historicising interrogation also highlights the inherently dialogical nature, character, and dynamics of the self in contemporary society, thus opening up the conceptual space to better grasp, theorise, and evaluate the irreducible complexity of self-formation.
\end{abstract}

Keywords: Self-Formation; Existentialism; Phenomenology; Social Saturation; Dialogical Self and Reflexivity 


\section{Introduction}

In general, theorising the notion of the self does not pertain to a clear, coherent, and commonly agreed history, and is indisputably not an easy thing (see Levine, 1985; Ormay, 2012; Barresi, 2002; Tsekeris, 2015). Additionally, in spite of the large number of relevant studies, the social scientific understanding of the self's "influence on behaviour, remains far from adequate" (Spinelli, 2005, p. 76).

Nowadays, however, it is strongly and interdisciplinarily acknowledged and accepted that the individual self is social to the core "because the processes of mind are the same as social processes. Both are processes of communicative interacting and power relating between human bodies in which individual minds form and are formed by social relations at the same time" (Stacey, 2003, p. 17). As Jean-Francois Lyotard in his influential Postmodern Condition has imaginatively put it, "no self is an island; each exists in a fabric of relations that is now more complex and mobile than ever before. Young or old, man or woman, rich or poor, a person is always located at 'nodal point' of specific communication circuits, however tiny these may be" (Lyotard, 1986, p. 15).

Hence, the self is relational through and through (Donati, 2014), that is, simultaneously subjective and social (Goffman, 1959; Simmel, 1971; Cooley, 1907), rather than a reified, separate, and lonely individual possession, that is, an entity "intrapsychically located, or able to be defined in isolation (as something in and of itself') or that it is the impetus to consciousness" (Spinelli, 2001, p. 43).

The issue of reflexivity is crucial here. According to the pragmatist perspective of George Herbert Mead, in particular, meaning is not based on the mere psychological (esoteric) constitution of the individual, but rather on the relational and interdependent "structure of social praxis" (Mead 1973, p. 69). Therefore, any human act indeed produces meaning if only it sufficiently contains an element of social reflexivity, which ensures the presence of symbolic consciousness (Mead 1973, p. 90). The everyday lifeworldly process of thinking and internalising the generalised other is "the very first stage of experience in the creation and development of the self" (Mead 1973, p. 147). As Charles Cooley comprehensively put it, "self and society go together, as phases of a common whole" (Cooley 1907, p. 678). Self and otherness constitute a mutually constitutive process. In the same spirit, the Croatian Protestant theologian Miroslav Volf (1996) perceptively elaborates on the innovative and influential conception of the other as occupying the self in the unceasing synergetic process of self-construction:

The human self is formed ... through a complex process of 'taking in' and 'keeping out.' ... a result of a distinction from the other and the internal 
ization of the relationship to the other; it arises out of the complex history of 'differentiation' in which both the self and the other take part by negotiating their identities in interaction with one another (Volf, 1996: 66).

The article then moves to briefly describe and discuss the rich and complex historicity of the self, as well as to highlight and assess some of its current epistemological elaborations, namely the existential-phenomenological framing and the notions of "social saturation" and "dialogical self".

\section{Historicising the Self}

Within contemporary social science, many scholars variously promote the idea that the self is a discursive, cultural, or historical construct, or relate it to human nature, personality, personhood, subjectivity, cognition, memory, or consciousness (the experience of self-awareness). Some others, who follow the neurobiological approach, define it exclusively in terms of the brain and neuro-anatomy, or theorise it as a product of the genome (Churchland, 2013).

De Villiers and Cilliers (2004) integratively "model" the selfas an evolutionary and material entity, "an emergent property of the complex system that consists of our mental apparatus, environment and language" (De Villiers and Cilliers, 2004, p. 52). In general, since William James's Principles of Psychology (1900), our theoretical and methodological understanding of the concept has changed significantly (Barresi, 2002).

But the roots of the self can be traced back to classical antiquity. Although not explicitly using the word "self", Socrates was the first who delineated a comprehensive ontological, epistemological and ethical framework for the systematic scholarly study of it, "through introspection and dialectic - through the interpersonal pursuit of truth. Thus, Socrates' implicit notion of the self is relational; the self is discovered in the process of discourse and dialogue with others" (Levin, 1992, p. 14). The intriguing reflexive imperative to know thyself, as it was written in the front of the famous temple of Apollo at Delphi, has exercised an enormous intellectual impact, as well as an "enduring moral fascination on generation after generation of thinkers" (Pels, 2000, p. 1).

Knowing yourself is for Socrates a unique virtue, not a Kantian descent into hell; it is therefore the central task for each person, since the unengaged, impassionate, and "unexamined life is not worth living" (Levin, 1992, p. 14). Exercising his own reflexivity, Nietzsche perceptively maintains that any great theoretical system equals to a self-confession on the part of its author "and a kind of involuntary and unconscious memoir" (Nietzsche, 1996, p. 37). Within such analytical contexts, re- 
flexive inquiry arguably pertains to an implicit notion that there is "a complexity and mystery about the self, that the self is a largely unexplained continent, the rivers, fields, and mountains of which are unknown to us" (Levin, 1992, pp. 14-15).

Furthermore, the irreducibly complex and nonlinear "nature" of the self seems to go hand in hand with its essentially conflictual character (seeSpinelli, 2001). In his famous dialogue Phaedrus, Plato (1961) was the very first to depict the self as conflictual, "as being constituted by what Freud called 'agencies of the mind' ... Self here is split and in constant conflict between opposing forces and tendencies” (Levin, 1992, p. 15).

In Phaedrus, more specifically, Plato imaginatively describes a tripartite model of the self, "using the metaphor of the chariot driver trying to control two spirited steeds. The chariot driver represents reason and control, a function akin to that of Freud's ego; one steed represents appetite and is a close relative of Freud's id, while the other steed represents ambition (i.e., the pursuit of narcissistic gratification). The second horse is also to be understood as the 'spirited' part of the self. There is no parallel to Freud's superego in Plato's model. The chariot driver is in perpetual need of establishing control over his horses" (Levin, 1992, p. 15).

In direct opposition to both Platonic perfection (idealism) and Cartesian reductionistic simplicity and cognitivism (or mentalism), Freud (1949) originally conceptualises human inner life as pertaining to a hugely complex system that contains a mysterious and unconscious dynamics, that is, a hidden deterministic dynamics of libidinal, instinctual, and emotional character.

In the contemporary epoch of late or high modernity, the self has rapidly become more emotional, but also more active, more intentional, and more transparent (yet complex and nonlinear), pertaining to a continuous open reflexive project (Giddens, 1991), or biographies of choice (Beck, 1992). As a consequence, identity (the traits possessed by a self) is now radically transformed "from a given into a task" (Bauman, 2001, p. 144; see also Elliott, 2001).

Nowadays, individuals are increasingly obliged to cope with chaos, uncertainty and living at risk, to find new life styles and design new life strategies, to seek to maximise their creativity and life chances, to take action in order to increase the quality of their lives, and to act prudently in relation to themselves and others. As life has become a strategic enterprise, the social and theoretical categories of health and illness have become vehicles for re-inventing the self and exercising subjectivities endowed with the faculties of choice and will (Greco, 1993). As active biological citizens, we are also required to diligently pursue life-long learn- 
ing and perpetual self-assessment, to constantly monitor our health, and to carefully manage emerging risks and susceptibilities. The formation of the self now inevitably takes place "in the languages and rhetorics of contemporary bioscience and biomedicine. Citizenship takes on new biological colourations and hope becomes bound up with scientific truth" (Rose, 2001, p. 12). Thus, the self becomes more relational.

\section{Existential-Phenomenological Considerations}

Relationalism overtly stands against any philosophical or sociological attempt to "essentialise" or "substantialise" the self (Tsekeris, 2013). The so called "relational reason" (Donati, 2014) consistently refrains from any old epistemological claim for a transcendental observer of all observers, which would rather amount to a contingent attempt to reduce the complexity and contingency of the self and the social world. In the same dynamical spirit, the existential-phenomenological tradition informs contemporary social science and champions the inherently protean, nonlinear and processual nature of the self, over against both totality and individuality/separateness, as well as both a false transcendence and an empty concreteness.

Most characteristically, Soren Kierkegaard's original and substantial philosophical approach to human subjectivity perceptively includes both objectivity and subjectivity, the world and the self, as grounded in concrete, lived human existence: “The self is the 'intermediate determinant' between psyche and soma and relates itself to both ... Kierkegaard's individualism is not egotistic or narcissistic; rather, it is relational in both relating itself to itself and relating itself to the Power that constitutes it. Kierkegaard explicitly warns against narcissistic self-absorption and schizoid withdrawal" (Levin, 1992, p. 126; see also Stewart, 2011). This processual, anti-essentialist and anti-substantialist worldview is also obvious in Ernesto Spinelli's "meta-dialogical" existential-phenomenological reconstructions on the relationally dependent self (Spinelli, 2001; 2005).

Existential-phenomenological reconstructions overtly signify that the self is contradictory, "paradoxical" or "polarised" (Schneider, 2013). Most importantly, we are not closed, distinct and separate entities, but open (Heideggerian) beings-in-the-world, deeply immersed in the inescapable conflicted complexity of a networked social reality. The meaningful lived perception and experience (in the here and now) of ourselves and others "emerge of, and through and irreducible grounding of relatedness ... no self can be 'found', nor individual 'emerge' other than via the a priori interrelational grounding from which our unique sense of being arises" (Spinelli, 2007, pp. 12, 14).

For Spinelli, who follows a Sartrean existential line of thought, relatedness essen- 
tially entails anxiety, uncertainty, and nonlinearity, as well as "co-operation with one another not because we have eradicated the conflict between us, but rather because our attempt at 'being for' one another arises through the mutual recognition of the inevitable conflict between us" (Spinelli, 2004, p. 62). Both cooperation and uniqueness emerge from our (unresolved) shared relatedness.

This explicitly rejects both the Scylla of subjectivism and the Charybdis of objectivism, in favor of a promising relational intersubjectivity, as famously echoed by the intersubjective existential-phenomenologist Martin Buber and his reflexive distinction between "I-It" and "I-Thou" (Buber, 2004). That means, "I can experience and relate to another as an object of my experience and self-consciousness and whose meanings can be reshaped and reformulated via the imposition of my preferred meaning stance" (Spinelli, 2005, p. 123).

For Buber (1947), dialogue implies that you cannot be the same as the Other. Having difference is an essential precondition to relationally bridge to another. This dialogics of self interprets and reconstructs "the self as 'becoming' on the boundaries of self and other, identity and difference" (Tziovas, 2003, p. 8).

The complex interrelational relationship between identity and otherness paved the radical philosophical way for the introduction of second-person intersubjective methodologies, such as the Bohmian interhuman dialogue, leading to innovative forms of dialogic consciousness (Bohm, 1985; see also Tsekeris, 2012). Ultimately, any original human experience is intrinsically grounded in an interpersonal relatedness between interacting social subjects: "One cannot become a human being in the abstract [...] Embeddedness is endemic to human experience - I become the person I am in interaction with others. The way I feel it necessary to be with them is the person I take myself to be" (Mitchell, 1988, pp. 275-276).

This profoundly posits once again the indispensable level of meaningful social interaction (in the living present) as the fundamental level of individual and collective behaviour, as well as of the personal and societal dynamics (Stacey, 2003). In addition, the emergent interrelational notion of the self-as-process radically transcends habituated scholarly dualisms and explicitly incorporates uncertainty as a ubiquitous feature of human social existence. As Jerome Bruner rightly observes, "when we enter human life, it is as if we walk on stage into a play whose enactment is already in progress - a play whose somewhat open plot determines what part we may play and toward what denouements we may be heading" (Bruner, 1990, p. 34).

Also, the self-as-process directly opposes to the "traditional" or "received" linear 
notion that our "inside" consists of different, separate and distinct levels or zones, functioning autonomously of each other and capable of being studied autonomously. Psychoanalysis, for instance, traditionally and erroneously tends to think of the "unconscious" - perceived as an "id" - as the most important thing in the whole psychological structure (Elias, 1982, pp. 284-285; see also Spinelli, 2001; 2005).

Over against process reduction and the old obsolete model of homo clausus, in Norbert Elias's (1970) scholarly Latin, our individuality is of necessity infused with our networked social existence, and vice versa; they are both mutually involved in an ongoing relational process of simultaneous (nonlinear) co-evolution, an "endless dance of co-emergence" (Waldrop, 1992, p. 75).

\section{Social Saturation and the Dialogical Self}

This interdisciplinary line of relational argumentation is imaginatively followed and furtheredbyKenneth Gergen's(2001)influential phenomenologicaland constructionist concept of the saturated self, which is strongly supported by a series of experiments (Gergen,1971).Thesaturated self referstothedramaticexplosion of nonlinearrelations (real, virtual, and imagined) in which the social individual is increasingly engaged.

In a sense, this notion of the human self pertains to a huge "expansion and complexifying of the individual's repertoire of 'ways of being' (e.g., attitudes, values, opinions, moralities, styles of relating), a compounding of evaluative standards applied to the self, an infinite expansion of opportunity, and an expanding sea of obligations. One becomes multiphrenic" (Gergen, 2007, original italics).

Social saturation and irreducible relational embeddedness, inseparability, and interdependence intimately amount to a major epistemological and historical shift in the well-respected romanticist and modernist (individually-centred) conceptions of the self. These are now actively and irreversibly replaced by "a postmodern conception of the self as inseparable from relationship. Replacing Descartes's centerpiece of the Enlightenment, 'I think, therefore I am', life in a socially saturated world invites the conclusion, 'I am connected, therefore I am"' (Gergen, 2007). In other words, individual selfhood has a foundational inter-relational grounding.

But although the saturated self ambitiously starts to offer a kind of promising alternative to the self-serving, static, atomistic and narcissistic self, it seems difficult to avoid the common postmodern pitfalls of the self as a (reductionist) mode of linguistic construction, as well as of the tenuous, decentered, provisional, inconsistent/incoherent and fragmented social agency (see Stepnisky, 2006). 
This is rather more adequately addressed by the social psychological and epistemological concept of the dialogical self, originally conceived by Hermans, Kempen and van Loon (1992) and heavily inspired from American theorists of the self, like William James and George Herbert Mead, as well as from the Russian dialogical school in the tradition of Mikhail Bakhtin's innovative theory of dialogism and heteroglossia in literary creation (see Barresi, 2002).

In general terms, the dialogical self refers to a dynamic interrelational multiplicity of I-positions within both internal and external interchanges. In a synthetic and integrative manner, this dialogical notion overtly acknowledges and celebrates both the modern emphasis on critical self-agency and the postmodern analytical focus on social construction, language, discourse, and power relations (Richardson et al., 1998; Hermans, 2014). The self, including the cyberself, is interdisciplinarily conceptualised here as socially embedded, relationally dynamic, and entirely open to an ambiguous otherness, continuously moving toward an uncertain, unforeseen, and unpredictable future, without however reaching a final and safe destination.

This general uncertainty is fundamentally coupled with a permanent nonlinear sense of playfulness, experimentation, fluidity and flexibility. Although the dialogical self is always bound to particular positions in time and space (including cyberspace), it also has the unique critical-reflexive capacity to imaginatively change or modify positions in accordance with various nonlinear fluctuations in situation and time. Fruitful dialogical and nonlinear relations between different positions (possibly pertaining to unequal power) can subsequently develop, because each position is endowed with a voice (perhaps a critical one).

According to such relational dialogical reconstructions, "there is no inner and outer, onlyabodyof context and experience which expressesitselfin a consummate reciprocity' in which we discern ourselves through the other” (Gordon, 1991, p. 43). Human beings can thus be better understood, studied and theorised in the analytical intersubjective context of the complex dynamicinterdependencies with their multiple selves, as well as with each other, within a constantly changing social and cultural environment.

The creative, fragile, and uncertain process of self-construction, in the particular form of story-formed identity, profoundly signifies an ongoing nonlinear interplay between subjective aspects of one's self (i.e. voiced self-aspects or I positions), as well as a never-ending interrelational dialogue between internal I positions and the significant others, with whom the reflexive individual is strongly communicating and interacting (Hermans et al., 1992; Hermans, 2014). Arguably, the relational existence or appearance of these "significant others" 
(actual, imagined, or implied) is completely integral to the evolutionary reflexive (spontaneous) emergence and development of dialogical selfhood. Yet, in the original social interpretivist sense of G.H. Mead's theory, the "other" is not only the other (significant) person, "but another perspective: another way in which the world is judged or appreciated" (Natanson, 1956, p. 64).

\section{Conclusion}

The relational conceptions of "social saturation" and "dialogical self" seem to be in parallel with the advent of liquid modernity (Bauman, 2000), within which the self is always and everywhere on the move, flexibly enacted in and through ongoing complex and multiple relations. This also strongly highlights the existential-phenomenological features of contemporary self-formation. Human beings reflexively constitute their relational selves through active dialogical engagement in emergent nonlinear processes of practical interdependency. We thus derive relational goods and relational evils from acting together (Archer, 2013). The good and the evil dialectically coexist in selfhood and our emerging networked social worlds (including the virtual ones).

In complexity terms, the self has the relational capacity to adapt, learn and change, to employ appropriate adjustment mechanisms, to maintain diverse and multiple nonlinear strategies and tactics, to explore its relational space of creative possibilities, and to encourage dialogue, variety, innovation, and surprise. In times of acute personal and social existential crisis, in particular, where the flow of information becomes too fast and the world seems to lose its hitherto predictability, controllability and shape, the nonlinear system of the self may disintegrate into instability, fall into stagnation, or leap to a new meaningful level of order or organisation (dissipative structure), given the relational empowerment provided by surrounding networks (Tsekeris, 2015).

In this analytical context, contemporary social science, instead of being a "detached observer" of human affliction and social loss, must responsibly equip individuals and groups with critical skills and practical dialogical competencies to exploit increased social complexity, nonlinearity, turbulence, and chaos. It must also empower the suffering individual self to reflexively re-connect with the social and its support mechanisms, as well as to effectively search for new fruitful configurations regarding social, political and economic citizenship (given the general disaffection towards old or traditional forms of citizenship). For contemporary social science, in some sense, this is a heavy task of carrying "the weight of the world" (Bourdieu et al., 1999), which oppresses people and causes them to suffer in numerous ways. 


\section{References}

Archer, M. 2013. Collective Reflexivity: A Relational Case for It, in: C. Powell and F. Dépelteau (Eds) Conceptualizing Relational Sociology: Ontological and Theoretical Issues. New York: Palgrave-MacMillan, 145-161.

Barresi, J. 2002. From "the thought is the thinker" to "the voice is the speaker": William James and the Dialogical Self, Theory and Psychology, 12(2), 237-250.

Bauman, Z. 2000. Liquid Modernity. Cambridge: Polity.

Bauman, Z. 2001. The Individualized Society. Cambridge: Polity.

Beck, U. 1992. Risk Society: Towards a New Modernity. London: Sage.

Bohm, D. 1985. Unfolding meaning: A weekend of dialogue. London: Routledge.

Bourdieu, P., Accardo, A. and Parkhurst-Ferguson, P. 1999. The weight of the world: Social suffering in contemporary society. Stanford: Stanford University Press.

Bruner, J. 1990. Acts of Meaning. Cambridge, MA: Harvard University Press.

Buber, M. 1947. Between Man and Man. London: Fontana.

Buber, M. 2004. I and Thou. London and New York: Continuum.

Churchland, P.S. 2013. Touching a Nerve: The Self as Brain. New York: Norton.

Cooley, C. 1907. Social consciousness. The American Journal of Sociology, 12(5), 675-694.

De Villiers, T. and Cilliers, P. 2004. Narrating the Self: Freud, Dennett and Complexity Theory.

South African Journal of Philosophy, 23(1), 35-53.

Donati, P. 2014. Transcending Modernity: The Quest for a Relational Society. Bologna: University of Bologna.

Elias, N. 1970. What is Sociology?. New York: Columbia University Press.

Elias, N. 1982. The civilizing process. Oxford: Blackwell.

Elliott, A. 2001. Concepts of the Self. Cambridge: Polity.

Freud, S. 1949. An Outline of Psychoanalysis. New York: Norton.

Gergen, K. 1971. The Concept of Self. New York: Holt, Rinehart and Winston.

Gergen, K. 2001. The Saturated Self: Dilemmas of Identity in Contemporary Life. New York: Basic Books.

Gergen, K. 2007. Saturated Self, in: G. Ritzer (Ed.) Blackwell Encyclopedia of Sociology. Oxford:

Blackwell Reference Online. Available at: http://www.sociologyencyclopedia.com/subscriber/tocnode.html?id=g9781405124331_yr2012_chunk_g978140512433125_ss1-313 (Accessed 18 March 2015)

Giddens, A. 1991. Modernity and Self-identity: Self and Society in the Late Modern Age. Cambridge: Polity.

Goffman, E. 1959. The Presentation of Self in Everyday Life. New York: Anchor.

Gordon, R. 1991. Intersubjectivity and the efficacy of group psychotherapy. Group Analysis, 24(1), 41-51.

Greco, M. 1993. Psychosomatic subjects and 'the duty to be well' - personal agency within medical rationality. Economy and Society, 22(3), 357-372.

Hermans, H. 2014. Self as a Society of I-Positions: A Dialogical Approach to Counseling. Journal of Humanistic Counseling, 53(2), 134-159.

Hermans, H., Kempen, H.J. and van Loon, R.J. 1992. The dialogical self: Beyond individualism and rationalism. American Psychologist, 47(1), 23-33.

James, W. 1900. Principles of Psychology, Vol. I. New York: Henry Holt.

Levin, J.D. 1992. The Self and Therapy. Chevy Chase, MD: International Psychotherapy Institute E-Books.

Levine, D.N. 1985. The flight from ambiguity: Essays in social and cultural theory. London: The 
University of Chicago Press.

Lyotard, J.-F. 1986. The Postmodern Condition: A Report on Knowledge. Manchester: Manchester University Press.

Mead, G. H. 1973. L’esprit, le soi et la société. Paris: PUF.

Mitchell, S. 1988. Relational Concepts in Psychoanalysis: An Integration. Cambridge: Harvard University Press.

Natanson, M. 1956. The Social Dynamics of George H. Mead. Washington, DC: Public Affairs Press.

Nietzsche, F. 1996. Beyond Good and Evil. Harmondsworth: Penguin.

Ormay, T. 2012. The Social Nature of Persons: One Person is No Person. London: Karnac Books.

Pels, D. 2000. Reflexivity: One Step Up, Theory, Culture \& Society, 17(3), 1-25.

Plato 1961. The collected dialogues. Princeton, NJ: Princeton University Press.

Richardson, F.C., Rogers, A. and McCarroll, J. 1998. Toward a dialogical self. American Behavioral Scientist, 41(4), 496-515.

Rose, N. 2001. The Politics of Life Itself. Theory, Culture \& Society, 18(6), 1-30.

Schneider, K. 2013. The polarized mind. Colorado Springs, CO: University Professors Press. Simmel, G. 1971. On Individuality and Social Forms. Chicago: The University of Chicago Press. Spinelli, E. 2001. The Mirror and the Hammer: Challenges to Therapeutic Orthodoxy. London: Sage.

Spinelli, E. 2004. Hell Is Other People: A Sartrean View of Conflict Resolution, International Journal of Existential Psychology and Psychotherapy, 1(1), 56-65.

Spinelli, E. 2005. The Interpreted World: An introduction to phenomenological psychology. London: Sage.

Spinelli, E. 2007. Practising Existential Psychotherapy: The relational World. London: Sage.

Stacey, R. 2003. Complex and Group Processes: A radically social understanding of the individual. London: Routledge.

Stepnisky, J.N. 2006. 『Narrative and Selfhood in the Antidepressant Era (Unpublished doctoral dissertation). College Park: University of Maryland.

Stewart, J. 2011. Kierkegaard and Existentialism. Aldershot: Ashgate.

Tsekeris, C. 2012. Advances in Reflexive Sociology: Theory, Agency and Dialogical Inquiry. Italian Sociological Review, 2(2), 66-75.

Tsekeris, C. 2013. Norbert Elias on Relations: Insights and Perspectives, in: C. Powell and F. Dépelteau (Eds) Conceptualizing Relational Sociology: Ontological and Theoretical Issues. New York: Palgrave-MacMillan, 87-104.

Tsekeris, C. 2015. Contextualising the self in contemporary social science. Contemporary Social Science, 10(1), 1-14.

Tziovas, D. 2003. The other self: Selfhood and society in modern Greek fiction. Lanham, MD:

Lexington Books.

Volf, M. 1996. Exclusion and embrace: A theological exploration of identity, otherness, and reconciliation. Nashville: Abingdon Press.

Waldrop, M. 1992. Complexity: The Emerging Science at the Edge of Order and Chaos. New York: Simon \& Schuster. 